\title{
Aqueous garlic extract improves renal clearance via vasodilatory/antioxidant mechanisms and mitigated proteinuria via stabilization of glomerular filtration barrier
}

Christian Eseigbe Imafidon ${ }^{1,2^{*}}$ (D) Rufus Ojo Akomolafe ${ }^{2}$, Omotayo Alaba Eluwole ${ }^{3}$, Isiaka Ayofe Adekunle ${ }^{2}$ and Ruby Adebusola Agbaje ${ }^{4}$

\begin{abstract}
Background: Lead $(\mathrm{Pb})$ remains an apparently indispensable material in several industrial processes. It is a potent environmental toxin with associated deleterious biological effects. The study investigated the effects of aqueous garlic extract (AGE) on renal clearance and proteinuria in Wistar rats with Pb-induced kidney injury.

Methods: Thirty male Wistar rats were divided into six groups of five rats each such that exposure to $\mathrm{Pb}$ (35 mg/kg i.p) for 10 consecutive days was either followed by 30 days recovery period (without treatment) or 30 days post-treatment with oral graded doses of AGE at 100, 200 and $400 \mathrm{mg} / \mathrm{kg}$ while comparisons where made against a control $(2 \mathrm{ml} / \mathrm{kg}$ NORMAL SALINE) at $p<0.05$. The phytochemical constituents of the extract were determined using conventional standard protocols before administration to the rats.

Results: $\mathrm{Pb}$ toxicity induced deleterious alterations of renal function biomarkers (creatinine, urea and total protein) in the plasma and urine, indicators of oxidative stress and lipid peroxidation (GSH, SOD, CAT and TBARS) in the kidney tissues as well as significantly lowered plasma and kidney NO level $(p<0.05)$ of the rats. It also significantly lowered creatinine clearance and fractional excretion of urea while urine total protein-creatinine ratio was significantly increased in the rats. Kidney histology showed evidence of $\mathrm{Pb}$-induced glomerular atrophy with tubular and interstitial vacuolation. However, AGE administration was associated with significant normalization of the aforementioned biochemical parameters $(p<0.05)$ as well as kidney histoarchitectural improvement. The pharmacological effects of AGE were attributed to its determined phytochemical constituents.
\end{abstract}

Conclusion: AGE normalized renal clearance through vasodilatory and antioxidant mechanisms with associated mitigation of proteinuria through stabilization of glomerular filtration barrier.

Keywords: Heavy metal, Lead, Garlic, Phytochemicals, Renal clearance, Proteinuria

\section{Background}

Kidney, the principal organ of homeostasis, performs both excretory and regulatory functions $[1,2]$. Renal dysfunction results in bioaccumulation of metabolic wastes which could be terminal (resulting in death), if left unchecked [3]. While some forms of kidney

\footnotetext{
* Correspondence: staywithchris@gmail.com

${ }^{1}$ Renal Research Laboratory, Department of Physiology, Faculty of Basic

Medical and Health Sciences, Bowen University Iwo, Iwo, Osun State, Nigeria

2Department of Physiological Sciences, Faculty of Basic Medical Sciences,

Obafemi Awolowo University, Ile-lfe, Osun State, Nigeria

Full list of author information is available at the end of the article
}

disorder are idiopathic, others have been associated with known causes namely genetic, lifestyle or chemicallyinduced (toxicological) [4-6]. Heavy metal toxicity, of which lead $(\mathrm{Pb})$ toxicity is important, plays a significant role in the pathogenesis of kidney disorder in many population $[5,7,8]$.

Lead $(\mathrm{Pb})$, occurring in both organic and inorganic forms in the environment, is a toxic heavy metal of environmental and occupational concern $[9,10]$. Due to its unique inherent qualities namely low melting point, resistant to corrosion, malleability, ductility and softness, 
$\mathrm{Pb}$ has found its relevance in several industrial processes such as in the production of paints, automobiles, water pipes, ceramics as well as electric storage batteries [9, 11]. Nevertheless, it is a non-biodegradable toxicant which when absorbed into the body (either by inhalation or ingestion) has an estimated biological half-life of about 10 years, thus enhancing bioaccumulation [10, 12]. Acting through disturbance of the antioxidant system, $\mathrm{Pb}$-induced oxidative stress is known to occur via any of the following two pathways in order to cause toxic effects; generation of reactive oxygen species (ROS) and depletion of antioxidant reserves through the generation of ROS $[13,14]$. According to literature, $\mathrm{Pb}$ toxicity is associated with deleterious biological effects including hemopoietic [15], nervous [12], reproductive [9], cardiovascular [16], gastrointestinal [10], hepatic [17] and kidney $[18,19]$ dysfunctions. Since the basic mechanism of $\mathrm{Pb}$-induced toxicity is disruption of the antioxidant system, therapeutic interventions are usually geared towards application of chelating agents namely dimercaprol (BAL), Calcium Disodium EDTA (CaNa2EDTA) and succimer (2, 3-meso-dimercaptosuccinic acid or DMSA). These chelating agents are expensive, not readily available and sometimes burdened with undesirable side effects $[9,20]$. This study aimed at exploring the therapeutic potential of a local (easily accessible) medicinal plant in an experimental model of $\mathrm{Pb}$-induced kidney injury.

It was reported by WHO that, in health care aids, medicinal plants are used among $80 \%$ of the world's population either as the plant extract or in the form of their active components due to their health beneficial effects [21]. Besides forming the basis for almost all medicinal therapy, herbs are contained in about $40 \%$ of prescriptions and interest for herbal remedies instead of synthetic drugs is on the increase due to their associated relatively lesser side effects [22, 23].

Garlic (Allium sativum) is a common and readily accessible plant that is cultivated both sexually and asexually [24]. It is a nutritional plant that is used as spice in food and has vast medicinal properties $[8,9]$. Some of its pharmacological activities namely anti-oxidant, anti-inflammatory, anti-biotic and anti-thrombotic effects have been experimentally demonstrated in conditions such as prostate cancer, cardiovascular disease, stroke, reproductive toxicity and kidney injury $[8,9,25]$. However, there is dearth of literature on the effects of garlic extract on the mechanisms of renal clearance and proteinuria in models of $\mathrm{Pb}$-induced kidney injury. This study aims to bridge this gap in knowledge.

\section{Materials and methods}

\section{Metabolic cages}

Metabolic cages were fabricated by Central Technological Laboratory and Workshops (CTLW), Obafemi
Awolowo University (OAU), Ile-Ife, Osun state, Nigeria [3, 26].

Plant material, lead salt, biochemical kits and chemicals Fresh garlic bulbs where purchased from a commercial supplier at Lagere market, Ile-Ife, Osun State, Nigeria and certified by a Botanist at the Department of Botany, Obafemi Awolowo University (OAU) where a voucher specimen was deposited.

Lead, in the form of lead acetate salt, was procured from Guangzhou Fischer Chemical Co., Ltd. (Guangdong, China).

Assay kits for renal function tests were purchased from Randox Laboratories Ltd. (United Kindgdom) while 1, 1Diphenyl-2-picryl-hydrazy (DPPH) was procured from Sigma Chemicals Co. (USA). All other chemicals used were of analytical grade, available commercially.

\section{Extraction process of aqueous garlic extract (AGE)}

The garlic bulbs were peeled, rinsed in tap water and thereafter weighed (W1). The weighed bulbs were pulverized in distilled water with the aid of a Waring blender (Waring Commercial, Torrington, CT). With the aid of an electric shaker, the resulting mixture was subjected to constant shaking for $12 \mathrm{~h}$ and thereafter filtered using $<2 \mu \mathrm{m}$ pore sieve. The filtrate, without been concentrated with a rotary evaporator, was directly fixed-dried in a lyophilizer at $-40^{\circ} \mathrm{C}$ (Ilshin Lab. Co. Ltd., Seoul, Republic of Korea). The yield obtained (aqueous garlic extract) was weighed (W2) and thereafter kept in a desiccator until when needed. The percentage yield of aqueous garlic extract (AGE) was calculated using the formula below; $[3,27,28]$.

$$
\begin{aligned}
& \text { Percentage yield of AGE }(\%)= \\
& \qquad \frac{\text { Yield of extract in gram }(\mathrm{W} 2)}{\text { Weight of freshly peeled bulbs in gram (W1) }} \times 100 \%
\end{aligned}
$$

Note: The extraction process of aqueous garlic extract (AGE) was carried out without the application of heat.

\section{Phytochemical screening of AGE}

Phytochemical screening of the extract was carried out in accordance with established standard laboratory protocols, described as follows;

The presence of alkaloids were qualitatively determined by the method of Halilu and co-workers [29] and quantified according to the method of Harbone [30]. Flavonoids were qualitatively determined by the method of Halilu and co-workers [29] and quantified by the method of Obadoni and Ochuko [31]. The presence of tannins was determined by the method of Halilu and co-workers [29] and thereafter quantified by the method of Allen and co-workers [32]. The presence 
of saponins was determined using Froth test as described by Benmehdi and co-workers [33] and thereafter quantified by the method of Obadoni and Ochuko [31]. The presence of phenolics was determined and quantified by the method of Edeoga and co-workers [34]. The presence of terpenoids was qualitatively determined by the method of Benmehdi and co-workers [33]. Qualitative analysis of cardiac glycoside was by Keller-Kiliani test as described by Anjali and Sheetal [35] while the quantitative analysis was by the method of Harbone [30].

\section{Determination of total flavonoid and total phenolic contents of AGE}

Total phenolic content of AGE was determined by the method of Singleton and Rossi [36] and as described by Gulcin and co-workers [37] using FolinCiocalteu's phenol reagent which is an oxidizing reagent. $0.2 \mathrm{ml}$ of Folin-Ciocalteu's phenol reagent was added to a mixture of $0.1 \mathrm{ml}$ of the sample and $0.9 \mathrm{ml}$ of distilled water. The resulting mixture was voltexed. After $5 \mathrm{~min}$ of standing, $1.00 \mathrm{ml}$ of $7 \%(\mathrm{w} / \mathrm{w}) \mathrm{Na}_{2} \mathrm{CO}_{3}$ solution was added and thereafter made up to $2.5 \mathrm{ml}$ with distilled water before the resulting mixture was incubated for $90 \mathrm{~min}$ at room temperature. Using an ultraviolet (UV)-Vis spectrophotometer (Labtronics, India; Model LT-290), the absorbance was read at a wavelength of $750 \mathrm{~nm}$ against a negative control which contained $1 \mathrm{ml}$ of distilled water. The gallic acid equivalent (GAE) of AGE was determined using gallic acid at $0.1 \mathrm{mg} / \mathrm{ml}$ as a standard, after preparing a calibration curve.

Total flavonoid content of AGE was determined using aluminum chloride colorimetric assay method according to Zhilen and co-workers [38] and as described by Miliauskas and co-workers [39]. Standard quercetin with varying concentrations $0.1,0.2,0.3,0.4$ and $0.5 \mathrm{mg} / \mathrm{ml}$ was used as standard in comparison to the AGE sample. $0.4 \mathrm{ml}$ of DW was added to $0.1 \mathrm{ml}$ of AGE/the standard, followed by $0.1 \mathrm{ml}$ of $5 \%$ sodium nitrate solution. After $5 \mathrm{~min}, 0.1 \mathrm{ml}$ of $10 \%$ aluminum chloride, and $0.2 \mathrm{ml}$ of sodium hydroxide solutions were added to the resulting mixture after which the volume was made up to $2.5 \mathrm{ml}$ with distilled water. The absorbance, at a wavelength of $510 \mathrm{~nm}$, was read against blank using a UV-vis spectrophotometer (Labtronics, India; Model LT-290).

The aforementioned tests were performed in triplicate, and the final results were expressed as mean \pm Standard Error of Mean in mg quercetin/GAE per gram of AGE using the formula below; [37, 39].

$$
\mathrm{X}=\mathrm{q}(\mathrm{V} / \mathrm{w})
$$

$\mathrm{X}=$ total content of flavonoid or phenolic compound in quercetin or GAE respectively;

$\mathrm{q}=$ concentration of quercetin or gallic acid established from the standard curve;

$\mathrm{V}=$ volume of $\mathrm{AGE}(\mathrm{ml})$; and.

$\mathrm{w}=$ weight of AGE sample.

\section{Radical scavenging activity of AGE}

The extract was evaluated for radical scavenging activity using Table 1, 1-diphenyl-2-picryl-hydrazy (DPPH) according to the method of Blois [40]. Butylated hydroxyl anisole (BHA) solutions as well as varied concentrations of the extract $(2.5,5,10$, and $20 \mathrm{~g} / \mathrm{ml})$ were taken into different test tubes. Four millilitres $(4 \mathrm{ml})$ of $0.1 \mathrm{mM}$ of DPPH was added to the test tubes, voltexed and allowed to stand at $27^{\circ} \mathrm{C}$ for $20 \mathrm{~min}$. Absorbance of the samples was measured at $517 \mathrm{~nm}$ against the absorbance of the control and their radical scavenging activities were calculated as follows; [40].

$$
\text { Radical scavenging activity }(\%)=\frac{1 \text {-Asample }}{\text { Acontrol }} \times 100
$$

\section{Determination of acute oral lethal dose $\left(\mathrm{LD}_{50}\right)$ of $\mathrm{AGE}$}

Acute oral lethal dose $\left(\mathrm{LD}_{50}\right)$ of $\mathrm{AGE}$ was determined by the method of Lorke [41] as modified by Imafidon and co-workers [27]. The modification of Lorke's procedure was the use of 2 rats per group in the second phase of the study; Lorke proposed the use of 1 rat per group at the second phase of $\mathrm{LD}_{50}$ determination.

A total of 17 adult Wistar rats were used for the determination of $\mathrm{LD}_{50}$. In the first phase of the

\begin{tabular}{|c|c|c|c|c|}
\hline$N=30$ & Group description & 10 days intraperitoneal administration & 30 days oral administration & 30 days recovery \\
\hline Group $1(n=5)$ & Control & NS $(2 \mathrm{ml} / \mathrm{kg})$ & NS $(2 \mathrm{ml} / \mathrm{kg})$ & $\mathrm{NS}^{\mathrm{a}}$ \\
\hline Group $2(n=5)$ & $\mathrm{Pb}$ & $\mathrm{Pb}(35 \mathrm{mg} / \mathrm{kg})^{\mathrm{a}}$ & _- & _- \\
\hline Group $3(n=5)$ & $\mathrm{Pb}+$ Recovery & $\mathrm{Pb}(35$ mg/kg) & - & $\mathrm{RP}^{\mathrm{a}}$ \\
\hline Group $4(n=5)$ & $\mathrm{Pb}+100 \mathrm{mg} / \mathrm{kg}$ AGE & $\mathrm{Pb}(35$ mg/kg) & $100 \mathrm{mg} / \mathrm{kg} \mathrm{AGE}^{\mathrm{a}}$ & - \\
\hline Group $5(n=5)$ & $\mathrm{Pb}+200 \mathrm{mg} / \mathrm{kg}$ AGE & $\mathrm{Pb}(35$ mg/kg) & $200 \mathrm{mg} / \mathrm{kg} \mathrm{AGE}^{\mathrm{a}}$ & _- \\
\hline Group $6(n=5)$ & $\mathrm{Pb}+400 \mathrm{mg} / \mathrm{kg} \mathrm{AGE}$ & $\mathrm{Pb}(35$ mg/kg) & $400 \mathrm{mg} / \mathrm{kg} \mathrm{AGE}{ }^{\mathrm{a}}$ & _- \\
\hline
\end{tabular}

Table 1 Experimental protocol and dose regimen

$N$ total number of rats, $n$ number of rats per group, $P b$ lead, $A G E$ aqueous garlic extract, $N S$ normal saline, $R P$ recovery period, ${ }^{a}$ point at which rats were sacrificed 
experiment, 9 rats were divided into 3 groups of 3 rats each and thereafter received graded doses of AGE at 10 $\mathrm{mg} / \mathrm{kg}, 100 \mathrm{mg} / \mathrm{kg}$ and $1000 \mathrm{mg} / \mathrm{kg}$ orally. The rats were observed for $24 \mathrm{~h}$ after which the first phase of the study was terminated.

In the second phase, 8 rats were divided into 4 groups of 2 rats each after which they received graded doses of AGE at $750 \mathrm{mg} / \mathrm{kg}, 1500 \mathrm{mg} / \mathrm{kg}, 3000 \mathrm{mg} / \mathrm{kg}$ and 6000 $\mathrm{mg} / \mathrm{kg}$ orally. They were also observed for $24 \mathrm{~h}$ after which the second phase of the study was terminated. Thereafter, the oral $\mathrm{LD}_{50}$ of AGE was determined using the formula below;

$$
\mathrm{LD}_{50}=\sqrt{\mathrm{a}} x \mathrm{~b}
$$

Where $\mathrm{a}=$ least dose that killed a rat; $\mathrm{b}=$ highest dose that did not kill a rat.

\section{Preparation of stock solution of $\mathrm{Pb}$ and $\mathrm{AGE}$}

Lead $(\mathrm{Pb})$, in the form of lead acetate [ $\mathrm{Pb}(\mathrm{CH} 3 \mathrm{COO}) 2]$, was used for the study. It was ensured that each $100 \mathrm{~g}$ rat received $0.2 \mathrm{ml}$ of any of the solutions in order to avoid fluid overload.

The stock solution of $\mathrm{Pb}$ was prepared by dissolving $35 \mathrm{mg}$ of lead acetate in $20 \mathrm{ml}$ of normal saline so that each $100 \mathrm{~g}$ rat received intraperitoneal injection of $0.2 \mathrm{ml}$ of $\mathrm{Pb}$ from the stock solution $(35 \mathrm{mg} / \mathrm{kg}$ of $\mathrm{Pb}$ ) for 10 consecutive days.

The stock solution for $100 \mathrm{mg} / \mathrm{kg}$ of AGE was prepared by dissolving $1 \mathrm{~g}$ of AGE in $20 \mathrm{ml}$ of normal saline. The stock solutions for $200 \mathrm{mg} / \mathrm{kg}$ and $400 \mathrm{mg} / \mathrm{kg}$ of AGE were prepared by dissolving $2 \mathrm{~g}$ and $4 \mathrm{~g}$ of AGE each in $20 \mathrm{ml}$ of normal saline respectively. The stock solutions for AGE were refrigerated after use while fresh samples were prepared every $48 \mathrm{~h}$ throughout the period of study.

\section{Animal management and experimental protocol}

The experimental protocols were in strict compliance with the guidelines for animal research, as detailed in NIH Guidelines for the Care and use of Laboratory Animals [42] and approved by local Institutional Research Committee.

Thirty male Wistar rats (aged 8-9 weeks old) weighing $120-150 \mathrm{~g}$ were used for this study. They were purchased from the Animal Holdings Unit of the College of Health Sciences, OAU, Ile-Ife where the study was carried out. Each rat was housed in a separate metabolic cage and was allowed access to standard rat chow (ACE Feeds Plc, Osogbo, Nigeria) and water ad libitum. The rats were allowed to acclimatize to life in the metabolic cages for two weeks before the study commenced. The rats were thereafter divided into six groups of five rats each as follows; Group 1 received normal saline $(2 \mathrm{ml} / \mathrm{kg})$ throughout the study period, after which they were sacrificed under ketamine anesthesia $(65 \mathrm{mg} / \mathrm{kg}$ i.m). Group 2 received $35 \mathrm{mg} / \mathrm{kg}$ of $\mathrm{Pb}$ (i.p) for 10 consecutive days after which they were euthanized under ketamine anesthesia. Group 3 were pretreated as group 2 and thereafter left for a recovery period of 30 days (without treatment) before they were also euthanized. Groups 4, 5 and 6 were pretreated as group 2 and thereafter received graded doses of AGE at 100,200 and $400 \mathrm{mg} / \mathrm{kg}$ respectively for 30 days before they were also euthanized (Table 1). Before the rats were euthanized, their $24 \mathrm{~h}$ urine samples were collected inside the metabolic cages. Blood sample from each rat was collected by cardiac puncture (under ketamine anesthesia) into separate lithium heparinized bottles and centrifuged at $4000 \mathrm{rpm}$ for 15 min using a cold centrifuge (Centrium Scientific, model 8881) at $-4{ }^{\circ} \mathrm{C}$. The plasma obtained was decanted into separate plain bottles using separate sterile syringes. The left kidney of each rat was excised and kept in a cooler for the preparation of homogenates while their right kidneys were fixed in 10\% formal-saline solution for histological examination.

\section{Biochemical assays}

Assessment of kidney function biomarkers, total protein concentration and plasma nitric oxide level

The biomarkers of kidney function namely creatinine and urea were assayed using Randox standard laboratory kits (Randox, UK) according to the manufacturer's instructions. However, creatinine clearance was calculated using the formula below;

$$
\text { Creatinine clearance }(\mathrm{ml} / \mathrm{min})=\frac{\mathrm{U}_{\mathbf{c}} \mathrm{V}}{\mathrm{P}_{\mathbf{c}}}
$$

Where Uc = urine creatinine concentration;

$\mathrm{V}=$ urine flow rate $=$ volume of urine/time; and.

$\mathrm{Pc}=$ plasma creatinine concentration .

The concentration of total protein was determined by the method of Lowry and co-workers [43] while nitric oxide level was determined by the method of Grisham and co-workers [44].

Note: For the conversion of S.I. units from $\mathrm{dl} / \mathrm{ml}$ to $\mathrm{mg} /$ $\mathrm{ml}$ in the determination of urine total protein-creatinine ratio, the following system of conversion was used; [26].

$$
1 \mathrm{dl}=100 \mathrm{~g}
$$

\section{Determination of fractional excretion of urea (FEurea)}

Fractional excretion of urea (FEurea) was determined using the formula below; [45]. 


$$
\text { FEurea }(\%)=\frac{\mathrm{U}_{\text {urea }} \times \mathrm{P}_{\mathrm{Cr}}}{\mathrm{P}_{\text {urea }} \times \mathrm{U}_{\mathrm{Cr}}} \times 100
$$

Where $\mathrm{U}_{\text {urea }}=$ urea concentration in the urine; $\mathrm{P}_{\text {urea }}=$ urea concentration in the plasma; $U_{\mathrm{Cr}}=$ creatinine concentration in the urine; and $\mathrm{P}_{\mathrm{Cr}}=$ creatinine concentration in the plasma.

\section{Assessment of oxidative stress status and lipid peroxidation}

With the aid of an electric homogenizer (SI601001), 10\% homogenate in phosphate buffer $(100 \mathrm{mM})$ was prepared with the left kidney tissue at a $\mathrm{pH}$ of 7.4. Thereafter, the homogenate was centrifuged at $3000 \mathrm{rpm}$ for $20 \mathrm{~min}$ and the supernatant was collected for the assessment of the following indices of oxidative stress;

Reduced glutathione (GSH) level was determined by the method of Beutler and co-workers [46], the activity of superoxide dismutase was determined by the method of McCord and Fridovich [47], catalase (CAT) activity was by the method of Sinha [48] while the level of thiobartiburic acid reactive substances (TBARS) was determined according to the method of Ohkawa and coworkers [49].

\section{Histological examination}

The right kidney of each rat was fixed in $10 \%$ formal-saline solution. Each kidney was thereafter dehydrated in graded alcohol and embedded in paraffin wax. Sections of about $7-8 \mu \mathrm{m}$ thick were subjected to Haematoxylin and Eosin ( $\mathrm{H} \& \mathrm{E})$ staining technique for photomicrographic assessment using Leica DM 750 camera microscope at $\times 400$ magnification.

\section{Statistical analysis}

Data were analyzed by one-way analysis of variance and expressed as mean \pm Standard Error of Mean. Thereafter, they were subjected to Newman Keul's post-hoc test and the level of significance was set at $p<0.05$. Differences between two variables was assessed using student's t-test. The statistical analysis was carried out using graph pad prism 5.03 (Graph Pad Software Inc., CA, USA).

\section{Results}

Percentage yield and phytochemical screening of AGE

The percentage yield of AGE was determined to be $69.47 \pm 0.51 \% \quad(n=3) \quad$ (Table 2) while phytochemical screening detected the presence of flavonoids, phenolics, cardiac glycosides, alkaloids, tannins and saponin in the extract (Table 3).
Table 2 Percentage yield of AGE

\begin{tabular}{llll}
\hline & $\begin{array}{l}\text { Weight of fresh } \\
\text { garlic bulbs }(\mathrm{g})\end{array}$ & $\begin{array}{l}\text { Yield of } \\
\text { AGE }(\mathrm{g})\end{array}$ & $\begin{array}{l}\text { Percentage yield of } \\
\text { AGE }(\%)\end{array}$ \\
\hline $\begin{array}{l}\text { 1st extraction } \\
\text { process }\end{array}$ & 500.00 & 342.35 & 68.47 \\
$\begin{array}{l}\text { 2nd extraction } \\
\text { process }\end{array}$ & 500.00 & 350.50 & 70.10 \\
$\begin{array}{l}\text { 3rd extraction } \\
\text { process }\end{array}$ & 500.00 & 349.25 & 69.85 \\
$\begin{array}{l}\text { The percentage yield of AGE after three separate extraction } \\
\text { processes }(n=3)=69.47 \pm 0.51 \%\end{array}$
\end{tabular}

Total flavonoid content, total phenolic content, radical scavenging activity and oral lethal dose of AGE

The extract was observed to have high amount of total flavonoid and phenolic contents in gram per milligram of their respective standards (Table 4) while the radical scavenging capacity was observed to increase with increasing doses (Fig. 1). Oral lethal dose $\left(\mathrm{LD}_{50}\right)$ of AGE was determined to be greater than $6000 \mathrm{mg} / \mathrm{kg}$ (Table 5).

\section{Effects of AGE on plasma and urine concentrations of creatinine, urea and total protein of Wistar rats with $\mathrm{Pb}$-induced kidney injury}

$\mathrm{Pb}$ administration was associated with a significant increase in the plasma creatinine concentration $(\mathrm{mg} / \mathrm{dl})$ of group 2 when compared with group $1(p<0.05)$. That of the AGE-treated groups 4, 5 and 6 were significantly lower when compared with groups 2 and 3, with no significant difference shown when compared with group 1 . The urine creatinine levels of groups 2 and 3 were significantly lower than that of group 1. Groups 4, 5 and 6 showed a significantly higher level of urine creatinine when compared with group $1(p<0.05)$ (Table 6).

There was a significant increase in plasma urea level (mg/dl) of groups 2 and 3 when compared with group 1 $(p<0.05)$. However, that of groups 4,5 and 6 were not significantly different from group $1(p>0.05)$. On the other hand, the urine urea concentration of groups 2 and 3 were significantly lower than that of group 1 while no

Table 3 Qualitative and quantitative determination of phytochemicals in AGE

\begin{tabular}{lll}
\hline Phytochemical constituents & Status & Percentage composition (\%) \\
\hline Flavonoids & + & $1.25 \pm 0.04$ \\
Phenolics & + & $1.70 \pm 0.02$ \\
Terpenoids & - & Nil \\
Cardiac glycosides & + & $3.00 \pm 0.15$ \\
Alkaloids & + & $0.85 \pm 0.05$ \\
Tannins & + & $3.60 \pm 0.15$ \\
Saponin & + & $0.55 \pm 0.04$ \\
\hline
\end{tabular}

Each value $(n=3)$ is expressed as Mean \pm Standard Error of Mean; $+=$ present; $-=$ absent 
Table 4 Total Phenolic and total flavonoid content of AGE

\begin{tabular}{ll}
\hline $\begin{array}{l}\text { Total phenolic content ( } \mathrm{mg} \\
\text { of GAE/g of AGE) }\end{array}$ & $\begin{array}{l}\text { Total flavonoid content (mg of quercetin } \\
\text { equivalent/g of AGE) }\end{array}$ \\
\hline $53.82 \pm 1.70$ & $69.20 \pm 7.50$
\end{tabular}

Each value represents Mean \pm Standard Error of Mean $(n=3)$; GAE gallic acid equivalent

significant difference was recorded in that of AGE-treated groups 5 and 6 when compared with group 1 (Table 6).

The plasma total protein concentration $\left[\times 10^{-2}(\mathrm{mg} / \mathrm{ml})\right]$ was significantly lowered in groups 2 and 3 when compared with group $1(p<0.05)$. That of groups 4,5 and 6 were significantly higher than groups 2 and 3 but showed no significant difference when compared with group 1 . On the other hand, the urine total protein concentration of groups 2 and 3 was significantly higher than that of group $1(p<0.05)$. However, the AGE-treated groups 5 and 6 showed no significant difference in urine total protein level when compared with group 1 (Table 6).

Effects of AGE plasma and kidney nitric oxide (NO) concentration, creatinine clearance and fractional excretion of urea (FEurea) of Wistar rats with $\mathrm{Pb}$-induced kidney injury

The plasma NO level $(\mu \mathrm{M})$ was significantly lowered in groups 2 and $3(0.39 \pm 0.03$ and $0.42 \pm 0.03$ respectively) when compared with group $1(1.14 \pm 0.04)(p<0.05)$. The AGE-treated groups 4,5 and $6(0.94 \pm 0.03 ; 1.12 \pm 0.03$ and $1.25 \pm 0.02$ respectively) showed significantly higher plasma NO level when compared with group $2(0.39 \pm 0.03)$ $(p<0.05)$ (Fig. 2).
Table 5 Acute oral toxicity test $\left(\mathrm{LD}_{50}\right)$ of $\mathrm{AGE}$

\begin{tabular}{lll}
\hline Number of rats & Dose $(\mathrm{mg} / \mathrm{kg})$ & Mortality \\
\hline 1st PHASE & 10 & $0 / 3$ \\
3 & 100 & $0 / 3$ \\
3 & 1000 & $0 / 3$ \\
3 & & \\
2nd PHASE & 750 & $0 / 2$ \\
2 & 1500 & $0 / 2$ \\
2 & 3000 & $0 / 2$ \\
2 & 6000 & $0 / 2$ \\
2 & & \\
\hline
\end{tabular}

Using Lorke's equation, $\mathrm{LD}_{50}=\sqrt{\mathrm{a}} \mathrm{x} \mathrm{b}$

$\mathrm{a}=\mathrm{nil} ; \mathrm{b}=6000 \mathrm{mg} / \mathrm{kg}$. Therefore, the acute oral lethal dose of AGE is greater than $6000 \mathrm{mg} / \mathrm{kg}$ (Oral LD $\mathrm{L}_{50}$ of AGE $>6000 \mathrm{mg} / \mathrm{kg}$ ). The adopted doses of AGE that were used for the main study were less than $10 \%$ of the oral $\mathrm{LD}_{50}$ of $\mathrm{AGE}$ (> $6000 \mathrm{mg} / \mathrm{kg}$ ); these include $100 \mathrm{mg} / \mathrm{kg}, 200 \mathrm{mg} / \mathrm{kg}$ and $400 \mathrm{mg} / \mathrm{kg}$ of AGE

The kidney NO level $(\mu \mathrm{M})$ was significantly lowered in groups 2 and $3(0.20 \pm 0.01$ and $0.24 \pm 0.01$ respectively) when compared with group $1(0.80 \pm 0.03)(p<0.05)$. The AGE-treated groups 5 and $6(0.76 \pm 0.02$ and $0.75 \pm$ 0.02 respectively) were significantly higher than groups 2 and $3(0.20 \pm 0.01$ and $0.24 \pm 0.01$ respectively) but showed no significant difference when compared with group $1(0.80 \pm 0.03)(p<0.05)$ (Fig. 2).

Groups 2 and $3(1.09 \pm 0.05$ and $1.13 \pm 0.06$ respectively) showed a significantly lowered creatinine clearance $\left[\times 10^{-2}(\mathrm{ml} / \mathrm{min})\right]$ when compared with group 1 $(3.38 \pm 0.22) \quad(p<0.05)$. However, the AGE-treated groups 5 and $6(3.37 \pm 0.12$ and $3.55 \pm 0.13$ respectively) showed no significant difference in creatinine clearance

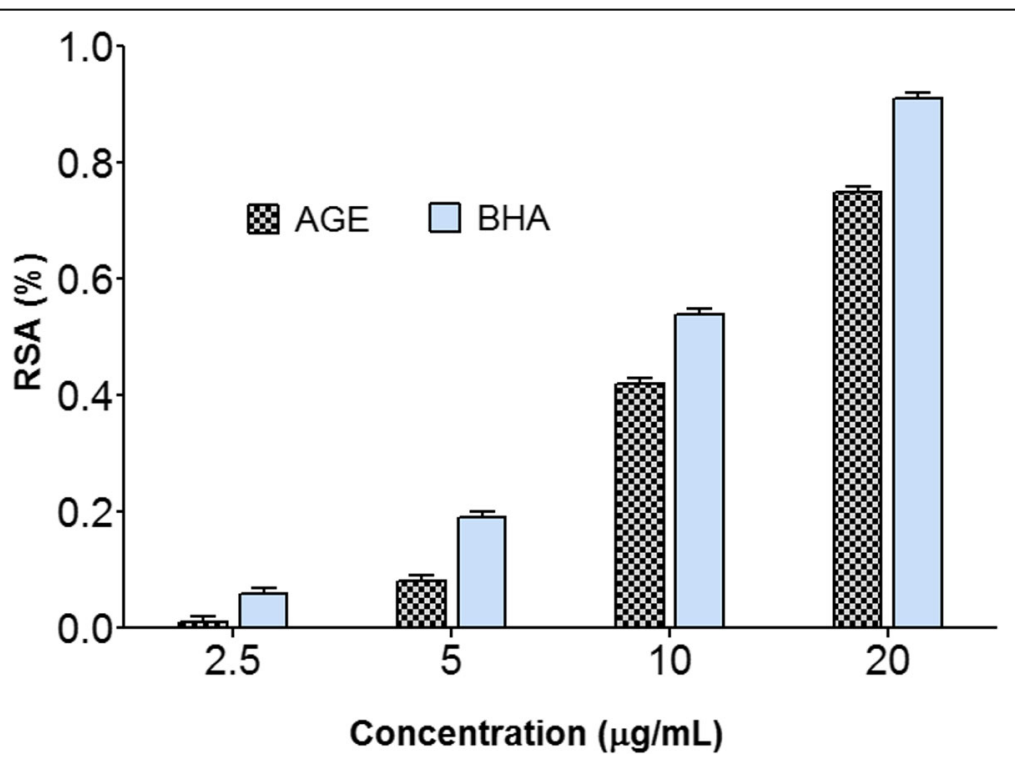

Fig. 1 Radical scavenging activity of aqueous garlic extract (AGE) at different concentrations. Graph showing concentration-dependent radical scavenging activity of AGE $(p<0.0001 ; F=650.85)$. Each value represents mean \pm Standard Error of Mean $(n=3)$; RSA = radical scavenging activity; $\mathrm{AGE}=$ aqueous garlic extract; $\mathrm{BHA}=$ butylated hydroxyl anisole 
Table 6 Effects of AGE on plasma and urine concentrations of creatinine, urea and total protein in Wistar rats with Pb-induced kidney injury

\begin{tabular}{|c|c|c|c|c|c|c|}
\hline \multicolumn{4}{|l|}{ Plasma concentration } & \multicolumn{3}{|c|}{ Urine concentration } \\
\hline Groups $(n=5)$ & $\begin{array}{l}\text { Creatinine (mg/ } \\
\text { dl) }\end{array}$ & Urea (mg/dl) & $\begin{array}{l}\text { Total protein }\left[\times 10^{-2}(\mathrm{mg} /\right. \\
\mathrm{ml})]\end{array}$ & $\begin{array}{l}\text { Creatinine (mg/ } \\
\text { dl) }\end{array}$ & Urea $(g / l)$ & $\begin{array}{l}\text { Total protein }\left[\times 10^{-2}\right. \\
(\mathrm{mg} / \mathrm{ml})]\end{array}$ \\
\hline [1] Control & $0.60 \pm 0.02$ & $33.50 \pm 0.71$ & $36.80 \pm 0.58$ & $13.08 \pm 0.28$ & $395.70 \pm 7.24$ & $23.80 \pm 0.58$ \\
\hline$[2] \mathrm{Pb}$ & $1.24 \pm 0.05^{\mathrm{a}}$ & $76.97 \pm 2.25^{a}$ & $13.60 \pm 1.03^{a}$ & $5.02 \pm 0.54^{a}$ & $202.60 \pm 4.57^{\mathrm{a}}$ & $72.00 \pm 1.64^{\mathrm{a}}$ \\
\hline [3] Pb + Recovery & $1.16 \pm 0.06^{\mathrm{a}}$ & $73.01 \pm 1.48^{\mathrm{a}}$ & $19.20 \pm 0.66^{\mathrm{ab}}$ & $5.81 \pm 0.25^{\mathrm{a}}$ & $230.70 \pm 14.95^{\mathrm{a}}$ & $69.20 \pm 1.77^{\mathrm{a}}$ \\
\hline $\begin{array}{l}\text { [4] Pb + } 100 \mathrm{mg} / \mathrm{kg} \\
\text { AGE }\end{array}$ & $0.63 \pm 0.02^{b c}$ & $58.32 \pm 2.20^{\mathrm{abc}}$ & $28.40 \pm 0.81^{\mathrm{abc}}$ & $9.06 \pm 0.41^{\mathrm{abc}}$ & $300.60 \pm 13.22^{\mathrm{abc}}$ & $29.40 \pm 1.03^{\mathrm{abc}}$ \\
\hline $\begin{array}{l}{[5] \mathrm{Pb}+200 \mathrm{mg} / \mathrm{kg}} \\
\text { AGE }\end{array}$ & $0.55 \pm 0.02^{b c}$ & $34.04 \pm 0.81^{\mathrm{bcd}}$ & $35.20 \pm 0.74^{\mathrm{bcd}}$ & $13.55 \pm 0.27^{\mathrm{abc}}$ & $384.30 \pm 18.24^{\mathrm{bcd}}$ & $22.00 \pm 0.31^{\mathrm{bcd}}$ \\
\hline $\begin{array}{l}{[6] \mathrm{Pb}+400 \mathrm{mg} / \mathrm{kg}} \\
\mathrm{AGE}\end{array}$ & $0.54 \pm 0.02^{b c}$ & $31.09 \pm 0.53^{\mathrm{bcd}}$ & $35.80 \pm 0.92^{b c d}$ & $13.98 \pm 0.22^{\mathrm{abc}}$ & $422.60 \pm 12.33^{b c d}$ & $24.40 \pm 0.68^{\mathrm{bcd}}$ \\
\hline
\end{tabular}

Each value represents mean \pm Standard Error of Mean (S.E.M.) at $p<0.05$

a = significantly different from control group [1],

b = significantly different from $\mathrm{Pb}$ group [2],

${ }^{c}=$ significantly different from $\mathrm{Pb}+$ recovery group [3], and

${ }^{\mathrm{d}}=$ significantly different from $\mathrm{Pb}+100 \mathrm{mg} / \mathrm{kg}$ group [4]

when compared with group $1(3.38 \pm 0.22)(p>0.05)$ but were significantly higher than groups 2 and $3(1.09 \pm$ 0.05 and $1.13 \pm 0.06$ respectively) (Fig. 2).

The fractional excretion of urea (\%) was significantly lowered in groups 2 and $3(19.62 \pm 2.13$ and $27.20 \pm 1.80$ respectively) when compared with group $1(54.29 \pm 1.00)$ $(p<0.05)$. Groups 5 and $6(58.18 \pm 1.91$ and $59.57 \pm 1.39$ respectively), however, showed a significantly higher fractional excretion of urea when compared with group $1(54.29 \pm 1.00)(p<0.05)$ (Fig. 2$)$.

\section{Effects of AGE on indicators of oxidative stress (GSH, SOD, CAT) and lipid peroxidation (TBARS) of Wistar rats with $\mathrm{Pb}$-induced kidney injury}

Kidney GSH level ( $\mu \mathrm{g} / \mathrm{mg}$ protein) was significantly lowered in groups 2 and 3 when compared with group 1 as well as the AGE-treated groups 4,5 and $6(p<0.05)$. However, the AGE-treated groups 5 and 6 showed no significant difference in the GSH level when compared with group 1 (Table 7).

Although the AGE-treated groups 4 and 5 showed a significantly lowered kidney SOD level ( $\mathrm{mM} / \mathrm{mg}$ protein) when compared with group $1(p<0.05)$, all AGE-treated groups 4,5 and 6 showed a significantly higher SOD level when compared with groups 2 and $3(p<0.05)$. SOD level of groups 2 and 3 was significantly lower than group $1(p<0.05)$ (Table 7$)$.

Groups 2 and 3 had a significantly lower kidney CAT level $(\mu \mathrm{mol} / \mathrm{min} / \mathrm{mg}$ protein) when compared with group 1 as well as the AGE-treated groups 4,5 and $6(p<$ 0.05). However, the AGE-treated groups 5 and 6 showed no significant difference in CAT level when compared with group $1(p>0.05)$ (Table 7).
Kidney TBARS level (nmol/mg protein) was significantly higher in groups 2 and 3 when compared with group 1 as well as the AGE-treated groups 4, 5 and 6 $(p<0.05)$. However, the AGE-treated groups 5 and 6 showed no significant difference in TBARS level when compared with group $1(p>0.05)$ (Table 7).

\section{Effects of AGE on urine total protein-creatinine ratio of Wistar rats with $\mathrm{Pb}$-induced kidney injury}

Groups 2 and $3(3.16 \pm 0.07$ and $3.18 \pm 0.11$ respectively) showed a significantly higher urine total protein-creatinine ratio $(\mathrm{mg} / \mathrm{g})$ when compared with group $1(2.82 \pm$ $0.04)$ and the AGE-treated groups 4,5 and $6(2.75 \pm$ $0.16 ; 2.55 \pm 0.04$ and $2.33 \pm 0.06$ respectively) $(p<0.05)$. However, that of groups 4 and $5(2.75 \pm 0.16$ and $2.55 \pm$ 0.04 respectively) showed no significant difference when compared with group $1(2.82 \pm 0.04)(p>0.05)$ while the AGE-treated group $6(2.33 \pm 0.06)$ had a significantly lower urine total protein-creatinine ratio when compared with group $1(2.82 \pm 0.04)(p<0.05)$ (Fig. 3).

\section{Histological effects of AGE on the kidney of Wistar rats with $\mathrm{Pb}$-induced kidney injury}

$\mathrm{Pb}$ administration was associated with histoarchitectural distortion that was characterized by atrophied and shrunken glomerulus as well as tubular and interstitial vacuolation in groups 2 . Also, the recovery group 3 showed evidence of sustained kidney histoarchitectural distortion with apparent vacuolation of renal tubules and medullary interstitium. Although representative micrograph of the AGE-treated group 4 showed evidence of atrophied glomerulus with mild tubular vacuolation, those of groups 5 and 6 had similar features with the micrographic evidence of group 1 which was 


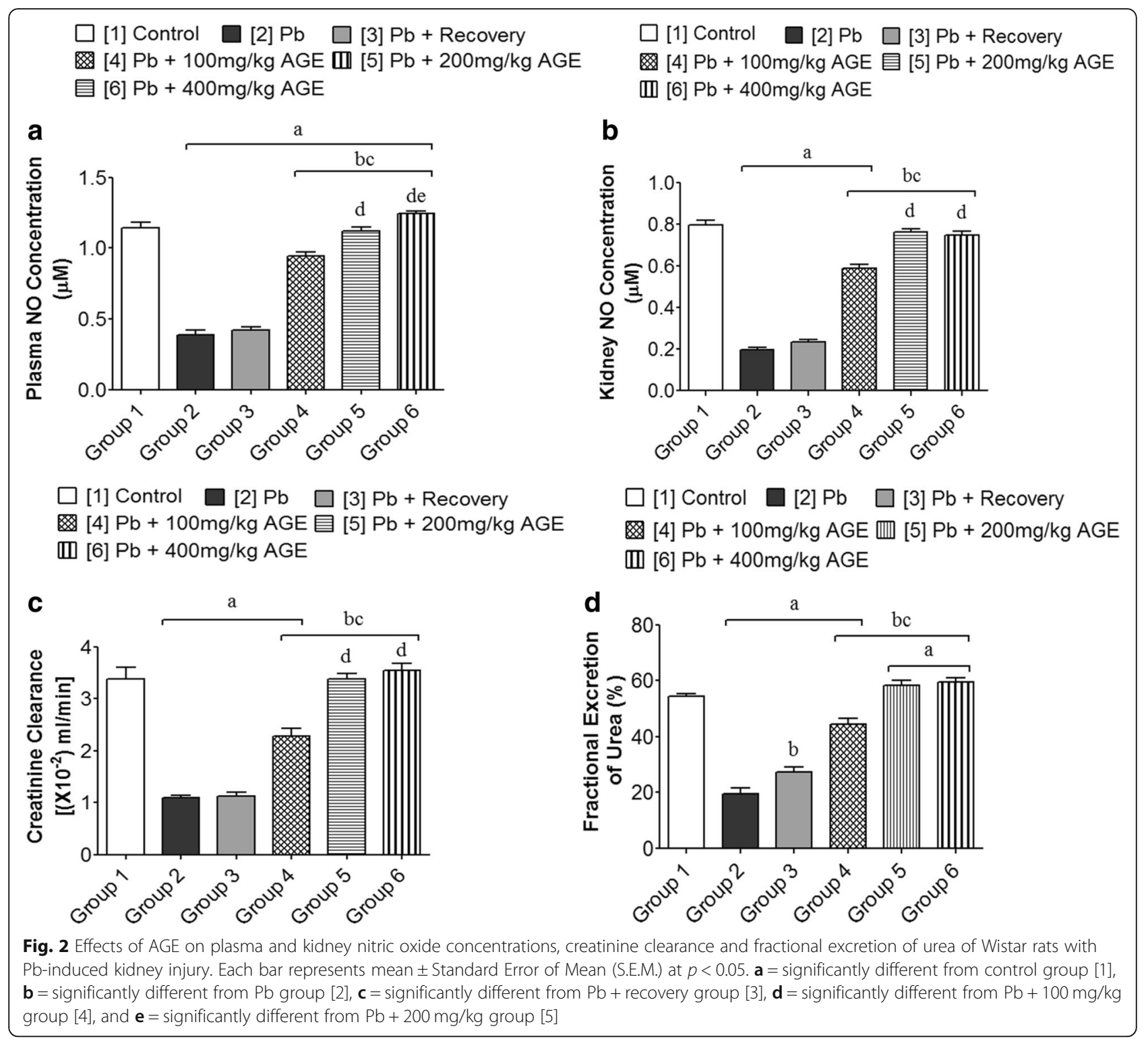

Table 7 Effects of AGE on kidney indicators of oxidative stress and lipid peroxidation in Wistar rats with Pb-induced kidney injury

\begin{tabular}{|c|c|c|c|c|}
\hline \multicolumn{4}{|c|}{ Indicators of oxidative stress } & \multirow{2}{*}{$\begin{array}{l}\text { Indicator of lipid peroxidation } \\
\text { TBARS (nmol/mg protein) }\end{array}$} \\
\hline Groups $(n=5)$ & GSH ( $\mu \mathrm{g} / \mathrm{mg}$ protein) & SOD (mM/mg protein) & CAT ( $\mu \mathrm{mol} / \mathrm{min} / \mathrm{mg}$ protein) & \\
\hline [1] Control & $3.36 \pm 0.11$ & $0.77 \pm 0.02$ & $2.30 \pm 0.05$ & $25.57 \pm 0.88$ \\
\hline [2] $\mathrm{Pb}$ & $0.95 \pm 0.07^{\mathrm{a}}$ & $0.22 \pm 0.01^{\mathrm{a}}$ & $0.76 \pm 0.04^{\mathrm{a}}$ & $74.88 \pm 1.53^{\mathrm{a}}$ \\
\hline [3] Pb + Recovery & $1.20 \pm 0.07^{\mathrm{a}}$ & $0.25 \pm 0.02^{\mathrm{a}}$ & $0.98 \pm 0.07^{\mathrm{ab}}$ & $65.24 \pm 1.90^{\mathrm{ab}}$ \\
\hline [4] $\mathrm{Pb}+100 \mathrm{mg} / \mathrm{kg} \mathrm{AGE}$ & $2.44 \pm 0.15^{\mathrm{abc}}$ & $0.55 \pm 0.02^{\mathrm{abc}}$ & $1.60 \pm 0.06^{\mathrm{abc}}$ & $44.24 \pm 1.95^{\mathrm{abc}}$ \\
\hline [5] $\mathrm{Pb}+200 \mathrm{mg} / \mathrm{kg}$ AGE & $3.24 \pm 0.07^{\mathrm{bcd}}$ & $0.69 \pm 0.02^{\mathrm{abcd}}$ & $2.20 \pm 0.07^{\mathrm{bcd}}$ & $26.52 \pm 0.36^{\mathrm{bcd}}$ \\
\hline [6] $\mathrm{Pb}+400 \mathrm{mg} / \mathrm{kg} \mathrm{AGE}$ & $3.51 \pm 0.09^{\mathrm{bcd}}$ & $0.76 \pm 0.02^{\text {bcde }}$ & $2.22 \pm 0.08^{\mathrm{bcd}}$ & $23.08 \pm 1.10^{\mathrm{bcd}}$ \\
\hline
\end{tabular}

Each value represents mean \pm Standard Error of Mean (S.E.M.) at $p<0.05$

${ }^{a}=$ significantly different from control group [1],

$\mathrm{b}=$ significantly different from $\mathrm{Pb}$ group [2],

$\mathrm{c}^{\mathrm{s}}=$ significantly different from $\mathrm{Pb}+$ recovery group [3],

${ }^{d}=$ significantly different from $\mathrm{Pb}+100 \mathrm{mg} / \mathrm{kg}$ group [4], and

${ }^{\mathrm{e}}=$ significantly different from $\mathrm{Pb}+200 \mathrm{mg} / \mathrm{kg}$ group [5] 


\section{[1] Control $\square$ [2] $\mathrm{Pb} \quad \square$ [3] Pb + Recovery \\ $[4] \mathrm{Pb}+100 \mathrm{mg} / \mathrm{kg}$ AGE 足 [5] Pb $+200 \mathrm{mg} / \mathrm{kg}$ AGE \\ س] [6] Pb + 400mg/kg AGE}

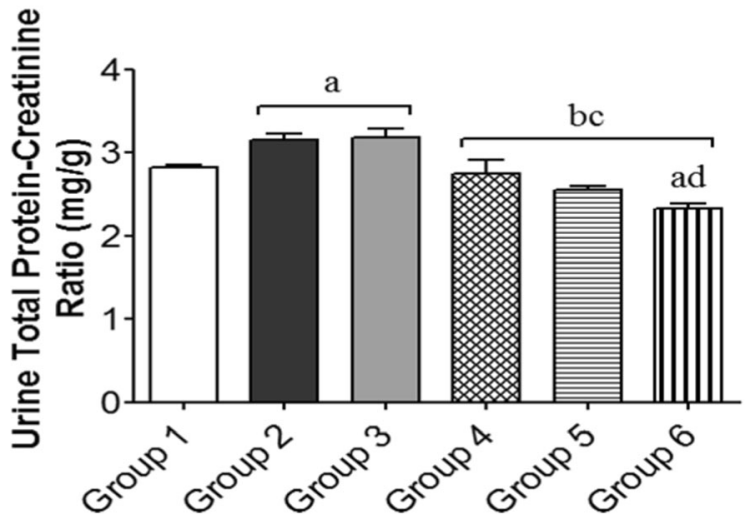

Fig. 3 Effects of AGE on urine total protein - creatinine ratio of Wistar rats with Pb-induced kidney injury. Each bar represents mean \pm Standard Error of Mean (S.E.M.) at $p<0.05$. $\mathbf{a}=$ significantly different from control group [1], $\mathbf{b}=$ significantly different from Pb group [2], $\mathbf{c}=$ significantly different from $\mathrm{Pb}+$ recovery group [3], and $\mathbf{d}=$ significantly different from $\mathrm{Pb}+100 \mathrm{mg} / \mathrm{kg}$ group [4]

characterized by an apparently normal glomerulus, renal tubules (proximal and distal) and apparently intact interstitium (Fig. 4).

\section{Discussion}

The study demonstrated the therapeutic effects of aqueous garlic extract (AGE) on the renal function of Wistar rats with $\mathrm{Pb}$-induced kidney injury. Worthy of note is the fact that preparation of the crude extract was without application of heat (direct lyophilizing of filtrate) in order to preserve any possible heat-labile constituent in the extract.

Abnormal levels of plasma and urine biomarkers of renal function that were associated with $\mathrm{Pb}$ administration, as shown in this study, are clear indications that this heavy metal $(\mathrm{Pb})$ induces both glomerular and tubular defects. This fact was well corroborated by the representative micrographic evidence which showed glomerular defects with tubular and interstitial vacuolation. Deleterious effects on the kidney's filtering ability are usually associated with a significant increase in plasma levels of renal function biomarkers, hence the determination of renal clearance is essential for the assessment of glomerular filtration rate $[50,51]$. This study showed that renal clearance was significantly reduced following $\mathrm{Pb}$ administration, with a consequent increase in the plasma level of creatinine and urea as well as significantly lowered urinary excretion of these

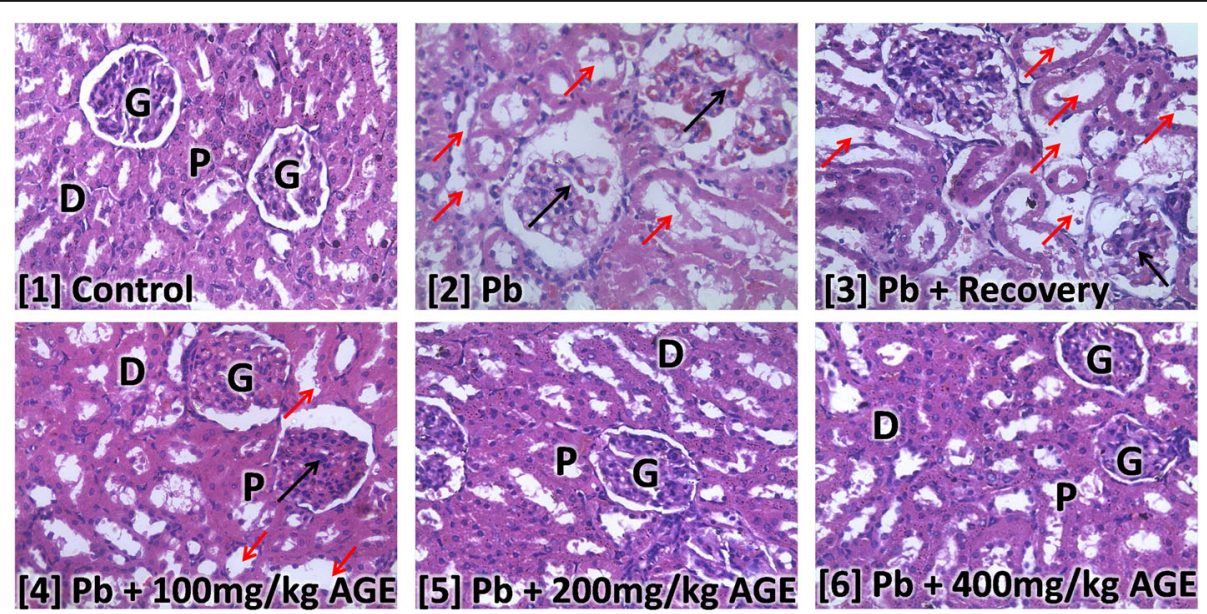

Fig. 4 Histological effects of AGE on the kidney of Wistar rats with Pb-induced kidney injury. Magnification = $\times 400$; [1] to [6] = groups 1 to 6; $\mathrm{AGE}=$ aqueous garlic extract; $\mathrm{Pb}=$ Lead; $\mathrm{G}=$ glomerulus; $\mathrm{P}=$ proximal tubule; $\mathrm{D}=$ distal tubule; Black arrow = atrophied glomerulus; Red arrow = tubular and interstitial vacuolation 
renal function biomarkers. This study, therefore, suggests that AGE has the potential to ameliorate $\mathrm{Pb}$-induced kidney injury via modulation of glomerular and renal tubular activities in order to bring about normalization of renal clearance. These effects were, however, enhanced by AGE-induced increase in renal perfusion via increased secretion of vasodilatory chemokine(s) (NO); facts that were demonstrated in this study by the increased levels of $\mathrm{NO}$ and fractional excretion of urea (FEurea). While increased vasodilatory effect of AGE was characterized by increased plasma and kidney NO level, the AGE-induced increase in renal perfusion was corroborated by a significant increase in FEurea following $\mathrm{Pb}$ administration. According to literature, $\mathrm{NO}$ is a potent vasodilator that has been reported to be essential for normal kidney function due to its vital role in renal mechanisms including renin release, extracellular fluid regulation, tubulo-glomerular feedback as well as regulation of glomerular and medullary hemodynamics $[52,53]$ while reduced FEurea level is a reflection of prerenal effects as a result of reduced renal perfusion [54, 55].

Furthermore, the $\mathrm{Pb}$-induced reduction in renal perfusion was associated with derangements of the antioxidant system as demonstrated by kidney activities of GSH, SOD, CAT as well as deleterious TBARS level (an index of lipid peroxidation). This suggests a possible renal ischemia reperfusion injury. Basically, ischemia reperfusion injury refers to cell injury or damage that results from the return of blood supply after a period of inadequate blood supply to any part of the body (ischemia) [56]. Chen and co-workers [57] reported that reperfusion injury induces reactive oxygen species (ROS) generation as a result of injury or damage to mitochondrial complexes. Since the kidney has capacity to auto regulate itself; maintaining a fairly constant blood supply despite fluctuations in arterial supply [1], it can be inferred that the observed significantly lowered circulating NO level must have coincided with compromised auto regulation capacity by the kidney of the $\mathrm{Pb}$-treated group for renal ischemia reperfusion injury to have occurred. The findings of this study suggests that $\mathrm{Pb}$ administration elicits deleterious effects on the renal antioxidant system through renal ischemia reperfusion injury. This mechanism apparently produced a secondary deleterious effect on renal clearance, as representative micrographic evidence showed $\mathrm{Pb}$-induced kidney histoarchitectural distortions that were characterized by atrophied glomerulus as well as tubular and interstitial vacuolation. It has been reported that the basic mechanism of $\mathrm{Pb}$-induced deleterious biological effects is disruption of the antioxidant system via ROS generation [9]. The significantly lowered endogenous antioxidants following $\mathrm{Pb}$ administration can be attributed to the increased usage of these antioxidants by the kidney to scavenge free radicals (ROS) and or reduced capacity of the renal system to replenish the used-up antioxidants in a corresponding rate at which they are being utilized. As predetermined in this study, AGE demonstrated a concentration-dependent free radical scavenging capacity (Fig. 1); making it an extract with potent antioxidant capacity with increasing doses. The administration of AGE was found to be associated with normalization of renal clearance via improved antioxidant system and significantly lowered kidney lipid peroxidation. Apparently, this presents the extract as a potential therapeutic choice in the adjuvant treatment or management of patients with renal oxidative stress that is associated with renal ischemia reperfusion injury. The pharmacological activities of the extract, as demonstrated by vasodilatory and antioxidant-boosting potentials were conferred by its important phytochemicals such as flavonoids, phenolics alkaloids and tannins (Table 3). According to literature, these phytochemicals are reputed to demonstrate antioxidant, anti-inflammatory and membrane-stabilizing properties both invivo and invitro [58-60].

$\mathrm{Pb}$ administration was associated with reduced plasma total protein concentration and a significantly higher urine total protein excretion when compared with the control. It is not unlikely that the decreased plasma total protein concentration may be a direct consequence of increased urine total protein excretion; since representative micrographic evidence showed apparently compromised glomerular filtration barrier. Nevertheless, this study demonstrated that $\mathrm{Pb}$-induced kidney injury elicits decreased protein synthesis (by the liver) into the circulation and or increased urinary excretion of total protein. Although, under apparently normal condition, Wistar rats excrete protein in their urine $[26,61,62]$, proteinuria was showed to be significantly higher in the toxic group following exposure to $\mathrm{Pb}$ toxicity when compared with the control. According to literature, minimal change nephropathy has been found to be associated with loss of negative charges that are normally present in the glomerular capillary basement membrane [63]. Basically, the physiologic relevance of the negatively charged basement membrane is to repel the negatively charged plasma proteins since like-charge repels [63]. Subject to further verification, it can be inferred that $\mathrm{Pb}$ toxicity enhances the rapid or increased loss of normal negative charges in the basement membrane since this loss is usually associated with the unhindered passage of plasma protein through the glomerular membrane into the urine. Besides the loss of negative charge, Imafidon and co-workers [26] reported that changes in renal histomorphometry (Bowman's capsular space, thickness and size of the glomerulus and Bowman's capsule as well as the endothelia fenestrae of the glomerular capillaries) 
reflects the capacity to express proteinuria in a relationship that is directly proportional; that is, increased size of these features is directly proportional to increased capacity to express proteinuria. Apparently, this translates to increased urine excretion of total protein due to defect(s) of the glomerular filtration barrier; apparently lager Bowman's capsular space. The representative micrographic evidence of the AGE-treated groups showed apparently improved or normal kidney histoarchitecture when compared with both the control and toxic groups, suggesting that the extract potentially stabilizes the glomerular filtration barrier via normalization of electric charges of the basement membrane as well as histological strengthening of the filtration barrier integrity to repel plasma protein. These pharmacological effects demonstrate that the extract possesses potential stabilizing effects on the glomerular filtration barrier as its administration was associated with mitigation of the $\mathrm{Pb}$-induced proteinuria; a finding that is worthy of further scientific exploration. In clinical models of kidney injury, a significantly increased urine total protein - creatinine ratio is an indication of a compromised renal function [64, 65]. Furthermore, the urine total protein - creatinine ratio trends with the level of proteinuria and allows for an effective monitoring of the progression of renal condition [65-67]. AGE administration significantly mitigated the $\mathrm{Pb}$-induced increase in urine total protein-creatinine ratio. This portrays the extract as a potential choice in the adjuvant treatment or management of nephropathies that are associated with proteinuria. Since $\mathrm{Pb}$ is a toxicant with a potential to bio-accumulate $[10,12]$, it may be inferred that a vital mechanism for the ameliorating effect of the extract is the inhibition of $\mathrm{Pb}$ bioaccumulation via increased (urinary) excretion from the body. This is, however, subject to further scientific verification as this study did not include urinary $\mathrm{Pb}$ quantification to its scope.

Based on the findings of this study, a mechanistic view of $\mathrm{Pb}$-induced kidney injury and the ameliorating effects of AGE have been summarized in Fig. 5.

Although this study does not indicate a clear-cut dosedependent renal effects of aqueous garlic extract, it however demonstrates that the therapeutic effects of the extract (on $\mathrm{Pb}$-induced kidney injury) increases with increasing doses. Additionally, at $400 \mathrm{mg} / \mathrm{kg}$ (the adopted highest dose for this study based on a pre-determined oral $\mathrm{LD}_{50}>6000 \mathrm{mg} / \mathrm{kg}$ ) the extract produced therapeutic effects on the renal function of Wistar rats. This implies that in an average human of $75 \mathrm{~kg}$ body weight, sub-chronic ingestion of the extract up to $30 \mathrm{~g}$ daily may be sufficient to produce therapeutic effects in conditions of $\mathrm{Pb}$-induced kidney injury. This is, however, subject to further scientific verification and human trials.

In order to reduce the risk of sustained/irreversible kidney injury or the progression of renal dysfunction to end stage renal damage, it is recommended that $\mathrm{Pb}-\mathrm{ex}$ posed subjects should resort to prompt and efficacious treatment or management therapy as recovery period without any form of treatment was shown, by this study,

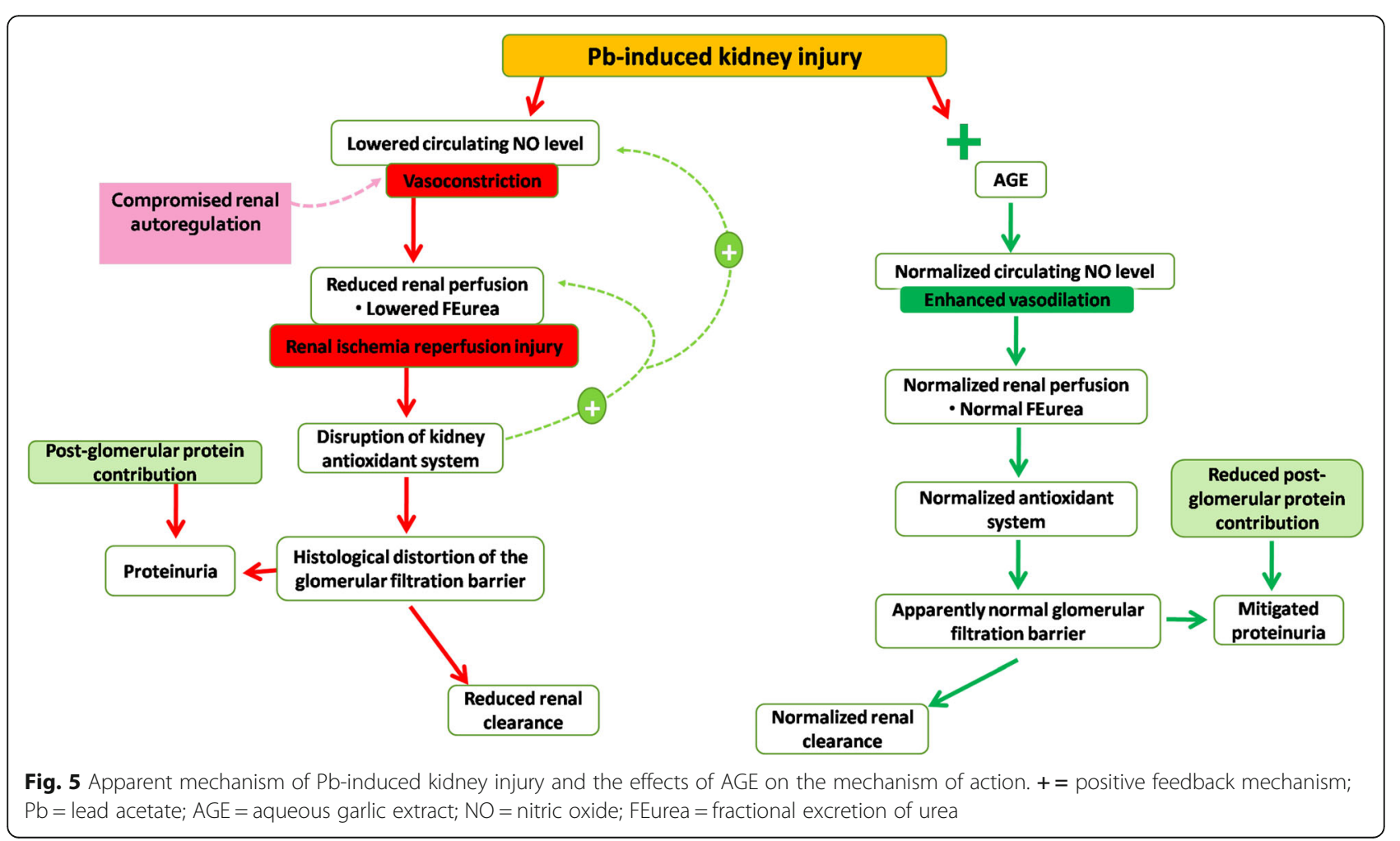


to sustain renal dysfunction. Based on the findings of this study, the consumption of garlic (to be used as spice in food or consumed raw) should be encouraged as it promotes healthy status through its beneficial biological effects. Further verification on the effects of the extract in surgically-induced renal ischemia reperfusion injury is also recommended. Although this study provides a template for further scientific exploration of effects of AGE on the glomerular filtration barrier, novel studies that takes into account the assessment or quantification of the negative charges on the glomerular basement membrane, special staining techniques for the assessment of the filtration membranes as well as novel appraisal of the glomerular filtration barrier using electron microscopy are highly recommended in this scope of research on environmental toxicology and pharmacology.

\section{Conclusion}

It was concluded that aqueous garlic extract normalized renal clearance through vasodilatory and antioxidant mechanisms as well as caused the mitigation of proteinuria through stabilizing effects on the glomerular filtration barrier in Wistar rats with $\mathrm{Pb}$-induced kidney injury.

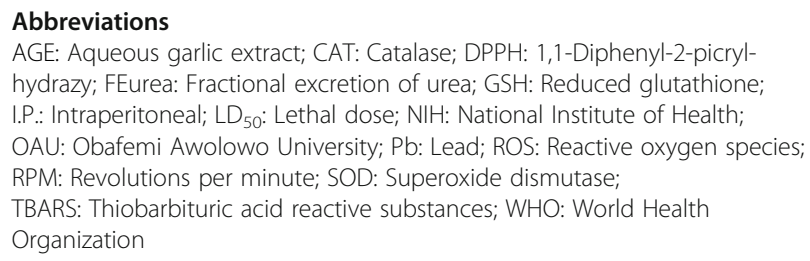

\section{Acknowledgements}

The authors acknowledge members of staff of Professor Obuotor's Laboratory, Department of Biochemistry and Molecular Biology, Obafemi Awolowo University (OAU), lle-lfe and the Central Technological Laboratory and Workshops (CTLW), OAU, Ile-lfe, Osun State, Nigeria for their kind support and technical assistance.

\section{Author's contributions}

ICE conceptualized the study. ICE, EOA and AIA were responsible for funding acquisition. ARO supervised and proof-read the manuscript for intellectual content. ARA and ICE carried out the biochemical analyses. All authors conducted the research, are responsible for data analyses, improvement of intellectual content and approval of final manuscript.

\section{Funding}

The authors received no form of funding support to carry out this research. The total cost of completing the research work was saddled by the authors.

\section{Availability of data and materials}

Not applicable.

\section{Ethics approval and consent to participate}

This study was approved by Health Research Ethic Committee (HREC) of the Institute of Public Health, Obafemi Awolowo, University, lle-lfe, Osun state, Nigeria.

\section{Consent for publication}

Not applicable

\section{Competing interests}

The authors declare that there are no competing interests regarding the publication of this paper.

\section{Author details}

${ }^{1}$ Renal Research Laboratory, Department of Physiology, Faculty of Basic Medical and Health Sciences, Bowen University Iwo, Iwo, Osun State, Nigeria. ${ }^{2}$ Department of Physiological Sciences, Faculty of Basic Medical Sciences, Obafemi Awolowo University, lle-lfe, Osun State, Nigeria. ${ }^{3}$ Department of Medical Pharmacology and Therapeutics, Faculty of Basic Medical Sciences, Obafemi Awolowo University, lle-Ife, Osun State, Nigeria. ${ }^{4}$ Department of Biochemistry and Molecular Biology, Faculty of Sciences, Obafemi Awolowo University, lle-lfe, Osun State, Nigeria.

Received: 29 April 2019 Accepted: 17 July 2019

Published online: 05 August 2019

\section{References}

1. Stuart IF. Human Physiology. In: McGraw-Hill. 12th ed; 2011. isbn:9780-07-337811-4

2. Walter FB. Medical physiology. In: a cellular and molecular approach. 1st ed, Elsevier/Saunders; 2004. isbn:978-0-8089-2449-4.

3. Adekunle IA, Imafidon CE, Oladele AA, Ayoka AO. Ginger polyphenols attenuate cyclosporine-induced disturbances in kidney function: potential application in adjuvant transplant therapy. Pathophysiol. 2018;25:101-15.

4. Bernard AM. Clinical renal toxicology. In: Sullivan JB, Krieger GR, editors. Clinical environmental health and toxic exposures. 2nd ed. Philadelphia: Lippincott Williams \& Wilkins; 2001. p. 281-9.

5. Ekong EB, Jaar BG, Weaver VM. Lead-related nephrotoxicity: a review of epidemiologic evidence. Kidney Int. 2006;70:2074-84.

6. Wedeen RP, Mallik DK, Batuman V. Detection and treatment of occupational lead nephropathy. Arch Intern Med. 1979;39:53-7.

7. Loumbourdis NS. Nephrotoxic effects of lead nitrate in Rana ridibunda. Arch Toxicol. 2003;77:527-32.

8. Oladimeji ST, Omotade IO, Olusola BA. Dietary protection of garlic extract against lead-induced oxidative stress and genetic birth defects. Oxid Antioxid Med Sci. 2014;3:79-82.

9. Ayoka AO, Ademoye AK, Imafidon CE, Ojo OE, Oladele AA. Aqueous extract of Allium sativum (Linn.) bulbs ameliorated pituitary-testicular injury and dysfunction in Wistar rats with $\mathrm{Pb}$-induced reproductive disturbances. Open Access Maced J Med Sci. 2016a;4(2):200-12.

10. Nikolas CP, Eleftheria GH, Stamatis B, George NT, Aristidis MT. Lead toxicity update: a brief review. Med Sci Monit. 2005;11(10):329-36.

11. Gagan F, Deepesh G, Archana T. Toxicity of lead: a review with recent updates. Interdiscip Toxicol. 2012;5:47-58.

12. Philip AT, Gerson B. Lead poisoning - part I. Clin Lab Med. 1994a;14:423-44.

13. Patrick NDL. Lead toxicity part II: the role of free radical damage and the use of antioxidants in the pathology and treatment of lead toxicity. Alternative Med Rev. 2006;11:114-27.

14. Sharifi AM, Ghazanfari R, Tekiyehmaroof N, Sharifi MA. Toxicology mechanisms and methods investigating the effect of lead acetate on rat bone marrow-derived mesenchymal stem cells toxicity: role of apoptosis. Toxicol Mech Methods. 2011;21:225-30.

15. Piomelli S. Childhood lead poisoning. Pediatr Clin N Am. 2002;49:1285-304.

16. Philip AT, Gerson B. Lead poisoning-part II. Effects and assay Cin Lab Med. 1994b;14:651-70.

17. Galleano M, Puntarulo S. Dietary al pha-tocopherol supplementation on antioxidant defenses after in vivo iron overload in rats. Toxicol. 1997;124:73-81.

18. Loghman-Adham M. Aminoaciduria and glycosuria following severe childhood lead poisoning. Pediatr Nephrol. 1998;12:218-21.

19. Khan N, Naqvi A, Perveen K, Rafique M. Lead induced nephrotoxicity with special reference to proximal tubule in albino rats. Pak J Pharmacol. 2008;25(1):29-35.

20. Doaa El-Nager M, Badr AA. Effect of corn oil, flax seed oil and black seed oil on testicular damage induced by lead acetate in albino mice: a histological study. Pakistan J Zool. 2013;45:1083-9.

21. WHO (World Health Organization), 2008). Traditional medicine. Retrieved from http://www.who.int/mediacentre/factsheets/fs134/en/. Accessed 01 Apr 2019. 
22. Craig WJ. Health-promoting properties of common herbs. Am J Clin Nutr. 1999;70(3):491-2.

23. Shirin APR, Jamuna P. Chemical composition and antioxidant properties of ginger root (Zingiber officinale). J Med Plant Res. 2010;4(24):2674-9.

24. Block E. Garlic and other alliums: the Lore and the science. In: Royal Society of Chemistry; 2010. isbn:0-85404-190-7.

25. Hilderbrand DC, Der R, Griffin WT, Fahim MS. Effect of lead acetate on reproduction. Am J Obstet Gynecol. 1973;115:1058-65.

26. Imafidon CE, Akomolafe RO, Oladele AA. Sexually dimorphic proteinuria in Wistar rats: relevance to clinical models. Pathophysiol. 2016;23:51-9.

27. Imafidon CE, Akomolafe RO, Sanusi AA, Ogundipe OJ, Olukiran OS, Ayowole OA. Polyphenol-rich extract of Vernonia amygdalina (Del.) leaves ameliorated cadmium-induced alterations in feeding pattern and urine volume of male Wistar rats. J Intercult. Ethnopharmacol. 2015;4:284-92. https://doi.org/10.5455/jice.20151107021034.

28. Online Math Learning.com. Percentage yield and percentage purity, 2015. Available from: http://www.onlinemathlearning.com/percent-yield.html. Accessed 03 Mar 2019.

29. Halilu ME, Abubakar A, Garbar MK, Isah AA. Antimicrobial and preliminary phytochemical studies of methanol extract of root bark of Crossopteryx febrifuga (Rubiaceae). J Appl Pharm Sci. 2012;2:066-70. https://doi.org/10. 7324/japs.2012.21212.

30. Harborne JB. Phytochemical methods. 2nd ed. London: Chapman and Hall; 1980. p. 288-93. https://doi.org/10.1007/978-94-009-5921-7.

31. Obadoni BO, Ochuko PO. Phytochemical studies and comparative efficacy of the crude extracts of some haemostatic plants in Edo and Delta states of Nigeria. Glob J Pure Appl Sci. 2002;8:203-8. https://doi.org/10.4314/gjpas.v8i2.16033.

32. Allen SE, Grinshaw HM, Parkinson JA, Quarmbay C. Chemical Analysis of Ecological Materials. 1st ed. London: Blackwell Scientific Publication; 1973. ISBN: 10: 0632003219

33. Benmehdi H, Hasnaoui $\mathrm{O}$, Benali $\mathrm{O}$, Salhi F. Phytochemical investigation of leaves and fruit extracts of Chamaerops humilis. Mater Environ Sci. 2012;3:320-37.

34. Edeoga HO, Okwu DE, Mbaebie BO. Phytochemical constituents of some Nigerian medicinal plants. Afr J Biotechnol. 2005;4(7):685-8.

35. Anjali $\mathrm{S}$, Sheetal $\mathrm{S}$. Phytochemical analysis and free radical scavenging potential of herbal and medicinal plant extracts. J Pharmacogn Phytochem. 2013;2:22-9.

36. Singleton $\mathrm{VL}$, Rossi JA. Colorimetry of total phenolics withphosphomolybdic-phosphotungstic acid reagents. Am J Enol Viticult. 1965;16:144-58.

37. Gulcin I, Oktay M, Kirecci E, Kufrevioglu OI. Screening of antioxidant and antimicrobial activities of anise (Pimpinella anisum L.) seed extracts. Food Chem. 2003;83:371-82.

38. Zhilen J, Mengeheng $T$, Jianming $W$. The determination of flavonoids contents in mulberry and their scavenging effects on superoxide radicals. Food Chem. 1999;64:555-9.

39. Miliauskas G, Venskutonis PR, Van Beek TA. Screening of radical scavenging activity of some medicinal and aromatic plant extracts. Food Chem. 2004:85:231-7.

40. Blois MS. Antioxidant determination by the use of stable free radical. Nature. 1958;181:1120-99. https://doi.org/10.1038/1811199a0.

41. Lorke D. A new approach to practical acute toxicity testing. Arch Toxicol. 1983:54:275-85. https://doi.org/10.1007/BF01234480.

42. NIH Guide for the Care and use of Laboratory Animals, 2011. 8th ed. Retrieved from https://grants.nih.gov/grants/./Guide-for-the-Care-and-use-oflaboratory-animals. [Accessed 01 Apr 2019].

43. Lowry OH, Nira JR, Farr LA, Rose JR. Protein measurement with the folinphenol reagent. J Biol Chem. 1951;193:265-75.

44. Grisham MB, Johnson GG, Lancaster JR. Quantitation of nitrate and nitrite in extracellular fluids. Methods Enzymol. 1996;268:237-46.

45. Carvounis CP, Nisar S, Guro-Razuman S. Significance of fractional excretion of urea in the differential diagnosis of acute renal failure. Ren Failure. 2002;62:2223-9.

46. Beutler E, Duron O, Kelly BM. Improved method for the determination of blood glutathione. J Lab Clin Med. 1963;61:882-8.

47. McCord JM, Fridovich I. Superoxide dismutase, an enzymic function for erythrocuprein (hemocuprein). J Biol Chem. 1969;244:6049-55.

48. Sinha KA. Colorimetric assay of catalase. Anal Biochem. 1971;47:389-94.

49. Ohkawa H, Ohishi N, Yagi K. Assay for lipid peroxides in animal tissues by thiobarbituric acid reaction. Anal Biochem. 1979;95:351-8.
50. Al-Qarawi AA, Rahman HA, Mousa HM, Ali BH, El-Mougy SA. Nephroprotective action of Phoenix dactylifera in gentamicin induced nephrotoxicity. Pharm Biol. 2008:46:227-30.

51. Valerie C, Scanlon TS. Essentials of Anatomy and Physiology. 5th ed. (Philadelphia): F.A. Davis Company; 2007. 13: 978-0-8036-1546-5

52. Oritz PA, Garvin JL. Role of nitric oxide in the regulation of nephron transport. Am J Physiol Renal Physiol. 2002;282(5):777-84.

53. Rezaei F, Mohhamad R. Comparison of saliva nitric oxide between chronic kidney disease before and after dialysis and with control group. Open Dent J. 2018;12:213-8.

54. Carlos FV, Gustavo G, Carlos S, Griselda B. Assessment of fractional excretion of urea for early diagnosis of cardiac surgery associated acute kidney injury. Ren Fail. 2015;37(10):327-31.

55. Christos PC, Sabeeha N, Samerah GR. Significance of the fractional excretion of urea in the differential diagnosis of acute renal failure. Kidney Int. 2002;62:2223-9.

56. Christopher BA, Homer-Vanniasinkham S. Clinical implications of ischemiareperfusion injury. Pathophysiol. 2003;9(4):229-40.

57. Chen Q, Moghaddas S, Hoppel CL, Lesnefsky EJ. Ischemia defects in the electron transport chain increase the production of reactive oxygen species from isolated rat heart mitochondria. Am J Physiol Cell Physiol. 2008;294(2):460-6.

58. Ayoka AO, Ojo EO, Imafidon CE, Ademoye AK, Oladele AA. Neuro-endocrine effects of aqueous extract of Amaranthus viridis (Linn.) leaf in male Wistar rat model of cyclophosphamide-induced reproductive toxicity. Toxicol Rep. 2016b;3:608-19. https://doi.org/10.1016/j.toxrep.2016.07.007.

59. Health Benefits of Flavonoids, 2016. Retrieved from http://www. livestrong.com/article/492244-whatare-the-health-benefits-of-flavonoids/. Accessed 01 Apr 2019.

60. Health Benefits of Plant Tannins, 2016. Retrieved from http://www. medibiztv.com/articles/health-tannins. Accessed 01 Apr 2019.

61. Jeannette MA, Hackbarth $H$, Deerberg F, Stolte H. Proteinuria in rats in relation to age-dependent renal changes. Lab Anim. 1980;14:95-101.

62. Perry SW. Proteinuria in the Wistar rat. J Pathol. 1965;89:729-33.

63. Ganong A, Kim EB, Susan MB, Scott B, Heddwen LB. Review of Medical Physiology. 23rd ed. New York: McGraw Hill; 2010. p. 639-85. isbn:9780-07-160568-7.

64. Cornell University College of Veterinary Medicine, Urine Protein to Creatinine Ratio. Retreived from https://www.vet.cornell.edu/animal-healthdiagnostic-center/testing/protocols/urinalysis. Accessed 22 July 2019.

65. Olaleye RO, Akomolafe RO, Imafidon CE, Ogundipe DJ, Olukiran SO, Oladele AA. Treatment with methanolic extract of Ocimum gratissimum (Linn.) leaf reversibly normalizes urine protein-creatinine ratio in Wistar rat model of gentamicin-induced kidney injury. Int J Med Biomed Res. 2016;5(3):155-71.

66. NICE CKD Guidance (2008). Early identification and management of chronic kidney disease in adults in primary and secondary care. Retrieved from http://www.nice.org.uk/nicemedia/pdf/CG073NICEGuideline.pdf [Accessed 03 Apr 2019].

67. Lees GE, Brown SA, Elliot J, Graver GF, Vaden SL. Assessment and management of proteinuria in dogs and cats: 2004 ACVIM forum consensus statement (small animal). J Vet Intern Med. 2005;19:377-85.

\section{Publisher's Note}

Springer Nature remains neutral with regard to jurisdictional claims in published maps and institutional affiliations. 